\title{
ASCORBIC ACID AS AN AUXILIARY TO ENHANCE COAGULATION FOR TURBIDITY AND TOTAL SOLIDS REMOVAL FROM GREYWATER
}

\author{
B. S. REVOLTA ${ }^{1}$, M. R. FRANCO JR ${ }^{2}$ \\ ${ }^{1,2}$ Faculdade de Engenharia Química, Universidade Federal de Uberlândia \\ E-mail para contato: moilton@ufu.br
}

\begin{abstract}
Alum-coagulation, Iron-coagulation and Iron- $\mathrm{NH}_{4}$ enhanced with ascorbic acid were used on the samples that were synthetically prepared and treated in reactors at ambient temperature to meet the Brazilian water quality discharge limits or to be reused. A series of jar test experiments was run at 150 rpm for $2 \mathrm{~min}$ and $30 \mathrm{~min}$ for settling. $95 \mathrm{mg} / \mathrm{L}$ dose of traditional coagulant (alum, iron or iron- $\mathrm{NH}_{4}$ ) was applied at $\mathrm{pH}$ ranging from 4-10. The coagulation was enhanced by adding doses of ascorbic acid resulting in three concentrations: $2.38,7.14$ and $11.9 \mathrm{~g} / \mathrm{L}$. Raw and coagulated greywater samples were analyzed for their turbidity, TS and conductivity as a function of time. The jar test experiments provided evidence that coagulation process could not provide sufficient TS removal efficiency in the greywater except at an iron- $\mathrm{NH}_{4}+$ acid in all concentrations of the acid reaching a maximum removal after 4-5 $\mathrm{h}$ decanting. Turbidity was better removed when the small concentrations of ascorbic acid was employed. Generally, enhanced coagulation process using ascorbic acid was not sufficient to meet turbidity $(<20 \mathrm{mg} / \mathrm{L})$ and TS $(100 \mathrm{mg} / \mathrm{L})$ limits. The highest turbidity removal $(95 \%)$ was obtained at the range of $2.0-4.3 \mathrm{pH}$ values, whereas turbidity removal was lesser in the greywater treated with Iron Chloride in the $11.90 \mathrm{~g} / \mathrm{L}$ concentration. All experiments with controlled $\mathrm{pH}$ resulted in treated greywater with increasing in conductivity. Conductivity was found significantly high when controlled $\mathrm{pH}$ was used in the coagulation process.
\end{abstract}

\section{INTRODUCTION}

The coagulation process proves a high removal efficiency of different parameters, mainly chemical oxygen demand (COD) and suspended solids (SS). The process is based on the use of $\mathrm{Al}$ (III) or $\mathrm{Fe}(\mathrm{III})$ salts alone or in combination with calcium salts and the use of polymers as flocculants. Coagulant doses vary in a wide range like $150-600 \mathrm{mg} / \mathrm{L}$ and 250 $2000 \mathrm{mg} / \mathrm{L}$ of $\mathrm{Al}_{2}\left(\mathrm{SO}_{4}\right)_{3}$ (alum) used for treatment of domestic [Meriç et al., 2002a,b; Delgado et al., 2003] and industrial wastewaters [Rossini et al.,1999; Selçuk et al., 2004], respectively while $20-60 \mathrm{mg} / \mathrm{L}$ of alum was applied as the proper interval for drinking water production [Volk et al., 2000; Rizzo et al., 2005]. In addition to aluminium sulfate, alternative coagulants, such as ferric chloride [Delgado et al., 2003], $\mathrm{NH}_{4}$-ferric chloride [Gao et al., 2002a-b,2003] can used trying to improve coagulation efficiency as well as associated with ascorbic acid in the water. Furthermore, the coagulation process was optimized for 
optimum time decanting and turbidity by results obtained when monitoring experiments were carried out.

The present study was carried out on synthetic greywater with specific composition to evaluate the efficacy of enhanced coagulation for complying with the brazilian discharge standards [Almeida et al., 2013] in the body water [Boneberg et al., 2013; Almeida \& Franco, 2013]. The effect of auxiliary coagulant in the coagulation $\mathrm{pH}$, applied alum dose, turbidity and TS concentrations on coagulation efficiency and removal $(\% \mathrm{R})$ was discussed.

\section{MATERIALS AND METHODS}

\subsection{Greywater and Jar test}

The synthetic greywater was prepared using: soap, oil and tap water in mass fraction $\%$ of: $0.068,0.581$ and 99.3 . Samples of $400 \mathrm{~mL}$ were distributed in glass containers to carry out jar test experiments. A series of jar tests was carried on the samples prepared daily in the laboratory. They were coagulated at $150 \mathrm{rpm}$ for $5 \mathrm{~min}$, sequentially stirred and then were settled for $30 \mathrm{~min} .95 \mathrm{mg} / \mathrm{L}$ dose of the dried traditional coagulant $\left\{\mathrm{Al}_{2}\left(\mathrm{SO}_{4}\right)_{3} ; \mathrm{FeCl}_{3}\right.$ or $\left.\mathrm{Fe}\left(\mathrm{NH}_{4}\right)\left(\mathrm{SO}_{4}\right)\right\}$ was used at $\mathrm{pH}$ ranging from 6.0 to 9.0. Ascorbic acid was added as an auxiliary coagulant in three distinct concentrations: $2.38 ; 7.18$ and $11.9 \mathrm{mg} / \mathrm{L}$, which is originally used in the experiments to enhance the coagulation process. Experiments with auxiliary coagulant were processed at $\mathrm{pH}$ ranging from 1.0 to 4.3.

Raw and coagulated samples were analyzed for their conductivity, TS and turbidity contents according to Standard Methods (1998). Samples of about $4.0 \mathrm{~mL}$ were collected using a syringe in different times such: $0.5 \mathrm{~h} ; 3 ; 4 ; 5$ and $24 \mathrm{~h}$.

\section{RESULTS AND DISCUSSION}

As already reported, only synthetic greywater with specific concentration was used in the experiments. So, conductivity, turbidity and TS concentrations were measured using three traditional coagulants associated with ascorbic acid at different concentrations.

Based on literatures reviewing (Selçuk et al., 2004; Almeida et al., 2013), the quality ranges of the different grey water are: $\mathrm{pH}$ (5.9-7.4), TSS (134-1300 mg/L) and turbidity (298 NTU). Although there are variations in grey water quality, the analysis of the grey water characteristics by different categories indicates that the kitchen grey water and the laundry grey water are higher in both organics and physical pollutants compared to the bathroom and the mixed grey water.

Figure 1 shows the behavior of greywater conductivity treated with $\mathrm{Al}_{2}\left(\mathrm{SO}_{4}\right)_{3}\left(\mathrm{C}=\left(95 \mathrm{mg}\right.\right.$. $\mathrm{L}^{-}$ ${ }^{1}$ ) enhaced with ascorbic acid. It can be observed that there is a minimum conductivity point between 3 and 5 hours in the settling time when the process probably could be finished. 


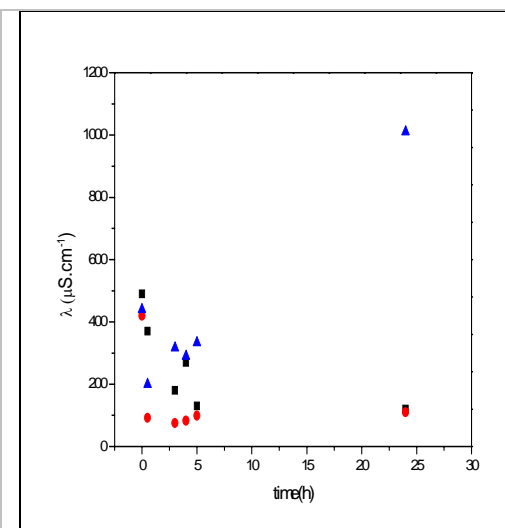

(a)

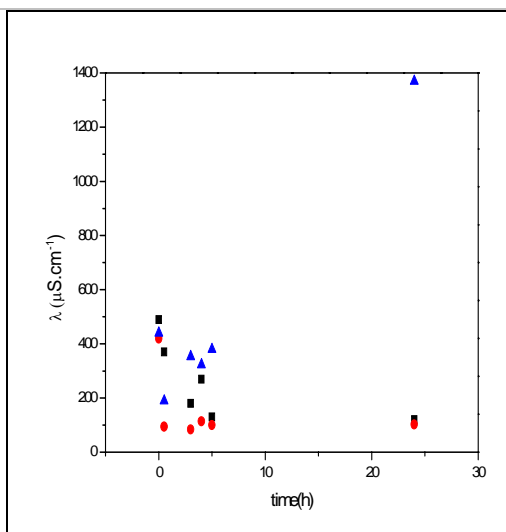

(b)

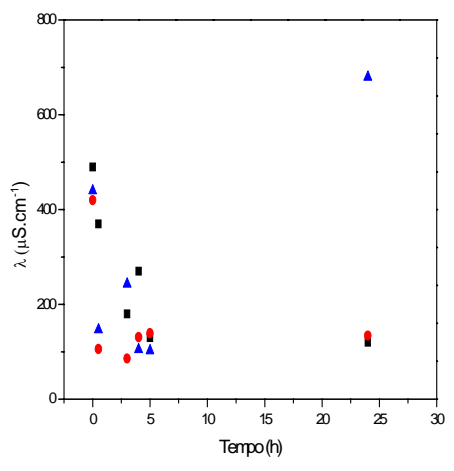

(c)

Figure 1. Conductivity of greywater treated with $\mathrm{Al}_{2}\left(\mathrm{SO}_{4}\right)_{3}\left(\mathrm{C}=\left(95 \mathrm{mg} \cdot \mathrm{L}^{-1}\right)\right.$ and associated with ascorbic acid at three different concentrations as a function of time. $\left\{\right.$ (a) 2.38 g.L $\mathrm{L}^{-1}$; (b) 7.14 g. $\mathrm{L}^{-1}$ e (c) 11.90 g. $\left.\mathrm{L}^{-1}\right\}$. ( • Coagulant, $\boldsymbol{\Delta}$ Coagulant + acid; - Coagulant + acid + pHcontrol).

One result for TS for the same system is presented in Figure 2. For this system, all results are listed in Table 1. It can be seen that adding sodium hydroxide solution to keep $\mathrm{pH}$ in the appropriate range ( $\mathrm{pH}$ control) leads the system to have high conductivity. It seems that the presence of ascorbic acid have not changed the grey water conductivity. Also, observing Figure 2, it is not recommended to leave the system decanting for more than seven hours.

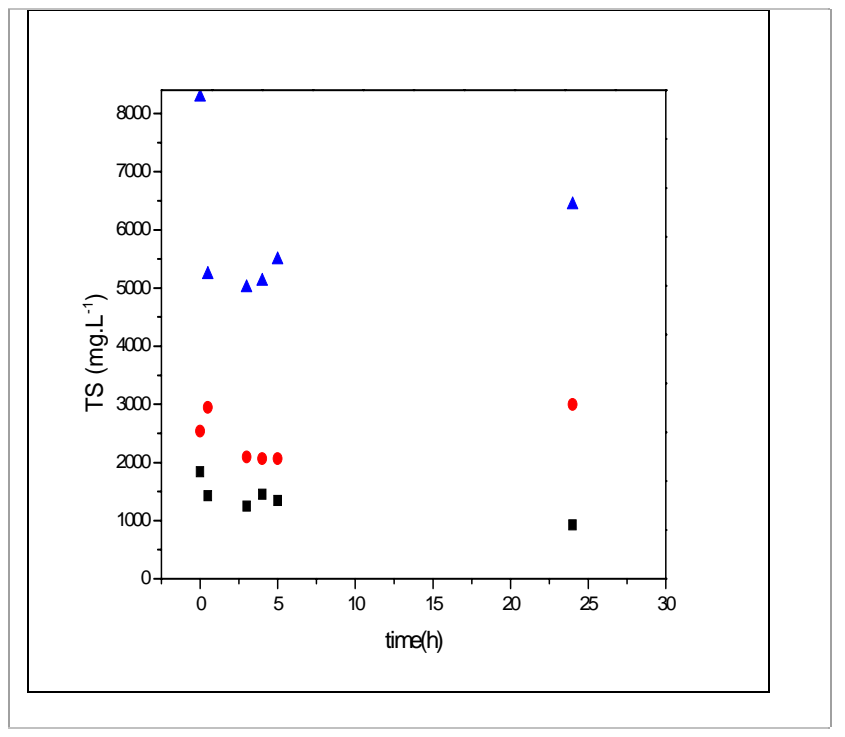

Figure 2. Total solids (TS) of greywater treated with $\mathrm{Al}_{2}\left(\mathrm{SO}_{4}\right)_{3}\left(\mathrm{C}=\left(95 \mathrm{mg} . \mathrm{L}^{-1}\right)\right.$ and associated with ascorbic acid at $2.38 \mathrm{~g} . \mathrm{L}^{-1}$ concentration as a function of time. 


\subsection{Overall removal calculations}

The removal $(\% R)$ of the total contaminants or impurities during the treatment was calculated using the following equations below. $\% R$ values for the impurities were determined and calculated according to the variable measured as shown in Eqs. (1) and (2):

$$
\begin{aligned}
& \% R^{\text {Turb }}=\left[\left(\text { Turb }_{0}-\text { Turb }_{t}\right] / \text { Turb }_{0}\right. \\
& \% R^{T S}=\left[\left(T S_{0}-T S_{t}\right] / T S_{0}\right.
\end{aligned}
$$

where, Turb 0 and $T S_{0}$ are initial turbidity and total solids in water, and $T u r b_{t}$ and $T S_{t}$ are the variables measured after coagulation process in the specific time. Removal efficiencies are listed in Tables 1-6 for all experiments.

Tables 2-6 show all the results of coagulation treatment for removal of impurities. According to them, treatment using only traditional coagulant is still seemed effective to remove impurities. The removal efficiency of TS also depended on the concentration of ascorbic acid. Results show that coagulation treatment was able to remove more than $40 \%$ of impurities from grey water. The removal efficiency was really lower when ascorbic acid concentration increased. Regarding the turbidity parameter, it was observed that removal efficiencies slightly improved with increasing dosage. However, for TS removal efficiencies were damaged by acid presence and remained unchanged when system was kept decanting all day long. This result indicates that the maximum dosage required for effective removal of these impurities from the grey water was $7.14 \mathrm{mg} / \mathrm{L}$. It seems that the fact of ascorbic acid is hardly soluble in water influences negatively in the TS results.

Table 1 - Total solids (TS) removing for $\mathrm{Al}_{2}\left(\mathrm{SO}_{4}\right)_{3}$ and associated with ascorbic acid at three different concentrations. (legend: No aux- only traditional coagulant; No $\mathrm{pH}-\mathrm{c}-$ without $\mathrm{pH}-$ control; $\mathrm{pH}-\mathrm{c}-\mathrm{pH}$-control used.)

\begin{tabular}{|c|c|c|c|c|c|c|c|c|c|}
\hline \multicolumn{9}{|c|}{ TS removing (\%) } \\
\hline \multirow{2}{*}{ Time/h } & \multicolumn{2}{|c|}{$2.38 \mathrm{mg} / \mathrm{L}$} & \multicolumn{3}{c|}{$7.14 \mathrm{mg} / \mathrm{L}$} & \multicolumn{3}{c|}{$11.9 \mathrm{mg} / \mathrm{L}$} \\
\cline { 2 - 11 } & $\begin{array}{l}\text { No } \\
\text { aux }\end{array}$ & $\begin{array}{c}\text { No } \\
\mathrm{pH}-\mathrm{c}\end{array}$ & $\mathrm{pH}-\mathrm{c}$ & $\begin{array}{c}\text { No } \\
\text { aux }\end{array}$ & $\begin{array}{c}\text { No } \\
\mathrm{pH}-\mathrm{c}\end{array}$ & $\mathrm{pH}-\mathrm{c}$ & $\begin{array}{c}\text { No } \\
\text { aux }\end{array}$ & $\begin{array}{c}\text { No } \\
\mathrm{pH}-\mathrm{c}\end{array}$ & $\mathrm{pH}-\mathrm{c}$ \\
\hline 0.5 & 23 & - & 37 & 23 & - & - & 23 & - & - \\
\hline 3.0 & 32 & 17 & 40 & 32 & - & - & 32 & - & - \\
\hline 4.0 & 21 & 19 & 38 & 21 & - & - & 21 & - & - \\
\hline 5.0 & 27 & 19 & 34 & 27 & - & - & 27 & - & - \\
\hline 24.0 & 50 & - & 22 & 50 & - & - & 50 & - & - \\
\hline
\end{tabular}


Table 2 - Turbidity removing for $\mathrm{Al}_{2}\left(\mathrm{SO}_{4}\right)_{3}$ and associated with ascorbic acid at three different concentrations.

\begin{tabular}{|c|c|c|c|c|c|c|c|c|c|}
\hline \multicolumn{9}{|c|}{ Turbidity removing (\%) } \\
\hline \multirow{2}{*}{ Time/h } & \multicolumn{2}{|c|}{$2.38 \mathrm{mg} / \mathrm{L}$} & \multicolumn{3}{c|}{$7.14 \mathrm{mg} / \mathrm{L}$} & \multicolumn{3}{c|}{$11.9 \mathrm{mg} / \mathrm{L}$} \\
\cline { 2 - 11 } & $\begin{array}{c}\text { No } \\
\text { aux }\end{array}$ & $\begin{array}{c}\text { No } \\
\mathrm{pH}-\mathrm{c}\end{array}$ & $\mathrm{pH}-\mathrm{c}$ & $\begin{array}{c}\text { No } \\
\text { aux }\end{array}$ & $\begin{array}{c}\text { No } \\
\mathrm{pH}-\mathrm{c}\end{array}$ & $\mathrm{pH}-\mathrm{c}$ & $\begin{array}{c}\text { No } \\
\text { aux }\end{array}$ & $\begin{array}{c}\text { No } \\
\mathrm{pH}-\mathrm{c}\end{array}$ & $\mathrm{pH}-\mathrm{c}$ \\
\hline 0.5 & 13 & 73 & 69 & 13 & 58 & 69 & 13 & - & 87 \\
\hline 3.0 & - & 48 & 75 & - & 80 & 70 & - & 20 & 49 \\
\hline 4.0 & - & 80 & 70 & - & 74 & 72 & - & 4 & 50 \\
\hline 5.0 & - & 88 & 76 & - & 78 & 74 & - & 2 & 53 \\
\hline 24.0 & 43 & 29 & 81 & 43 & 29 & 76 & 43 & 59 & 70 \\
\hline
\end{tabular}

Table 3 - Total solids (TS) removing for $\mathrm{FeCl}_{3}$ and associated with ascorbic acid at three different concentrations.

\begin{tabular}{|c|c|c|c|c|c|c|c|c|c|}
\hline \multicolumn{9}{|c|}{ TS removing (\%) } \\
\hline \multirow{2}{*}{ Time/h } & \multicolumn{2}{|c|}{$2.38 \mathrm{mg} / \mathrm{L}$} & \multicolumn{3}{c|}{$7.14 \mathrm{mg} / \mathrm{L}$} & \multicolumn{3}{c|}{$11.9 \mathrm{mg} / \mathrm{L}$} \\
\cline { 2 - 11 } & $\begin{array}{l}\text { No } \\
\text { aux }\end{array}$ & $\begin{array}{c}\text { No } \\
\mathrm{pH}-\mathrm{c}\end{array}$ & $\mathrm{pH}-\mathrm{c}$ & $\begin{array}{c}\text { No } \\
\text { aux }\end{array}$ & $\begin{array}{c}\text { No } \\
\mathrm{pH}-\mathrm{c}\end{array}$ & $\mathrm{pH}-\mathrm{c}$ & $\begin{array}{c}\text { No } \\
\text { aux }\end{array}$ & $\begin{array}{c}\text { No } \\
\mathrm{pH}-\mathrm{c}\end{array}$ & $\mathrm{pH}-\mathrm{c}$ \\
\hline 0.5 & - & - & - & - & - & - & - & - & - \\
\hline 3.0 & 17 & - & - & 17 & - & - & 17 & - & - \\
\hline 4.0 & 28 & 17 & - & 28 & - & - & 28 & - & - \\
\hline 5.0 & 38 & 10 & - & 38 & - & - & 38 & - & - \\
\hline 24.0 & 32 & - & - & 32 & - & - & 32 & - & - \\
\hline
\end{tabular}

Table 4 - Turbidity removing for $\mathrm{FeCl}_{3}$ and associated with ascorbic acid at three different concentrations.

\begin{tabular}{|c|c|c|c|c|c|c|c|c|c|}
\hline \multicolumn{9}{|c|}{ Turbidity removing (\%) } \\
\hline \multirow{2}{*}{ Time/h } & \multicolumn{2}{|c|}{$2.38 \mathrm{mg} / \mathrm{L}$} & \multicolumn{3}{c|}{$7.14 \mathrm{mg} / \mathrm{L}$} & \multicolumn{3}{c|}{$11.9 \mathrm{mg} / \mathrm{L}$} \\
\cline { 2 - 11 } & $\begin{array}{c}\text { No } \\
\text { aux }\end{array}$ & $\begin{array}{c}\text { No } \\
\mathrm{pH}-\mathrm{c}\end{array}$ & $\mathrm{pH}-\mathrm{c}$ & $\begin{array}{c}\text { No } \\
\text { aux }\end{array}$ & $\begin{array}{c}\text { No } \\
\mathrm{pH}-\mathrm{c}\end{array}$ & $\mathrm{pH}-\mathrm{c}$ & $\begin{array}{c}\text { No } \\
\text { aux }\end{array}$ & $\begin{array}{c}\text { No } \\
\mathrm{pH}-\mathrm{c}\end{array}$ & $\mathrm{pH}-\mathrm{c}$ \\
\hline 0.5 & 3 & 7 & - & 3 & - & 16 & 3 & - & - \\
\hline 3.0 & - & 36 & - & - & 9 & 18 & - & - & 10 \\
\hline 4.0 & - & 30 & 2 & - & 27 & 17 & - & - & 11 \\
\hline 5.0 & - & 43 & 14 & - & 33 & 21 & - & - & 10 \\
\hline 24.0 & 14 & - & - & 14 & - & - & 14 & - & 31 \\
\hline
\end{tabular}


Table 5 shows that the results seemed to be really similar for removing percentage when $\mathrm{Fe}\left(\mathrm{SO}_{4}\right)_{-} \mathrm{NH}_{4}$ is used even if acid concentration is increased. Also, controlling $\mathrm{pH}$ does not cause any change in the values as a function of time.

Table 5 - Total solids (TS) removing for $\mathrm{Fe}\left(\mathrm{SO}_{4}\right) \mathrm{NH}_{4}$ and associated with ascorbic acid at three different concentrations.

\begin{tabular}{|c|c|c|c|c|c|c|c|c|c|}
\hline \multicolumn{10}{|c|}{ TS removing (\%) } \\
\hline \multirow{2}{*}{ Time/h } & \multicolumn{2}{|c|}{$2.38 \mathrm{mg} / \mathrm{L}$} & \multicolumn{3}{c|}{$7.14 \mathrm{mg} / \mathrm{L}$} & \multicolumn{3}{c|}{$11.9 \mathrm{mg} / \mathrm{L}$} \\
\cline { 2 - 11 } & $\begin{array}{c}\text { No } \\
\text { aux }\end{array}$ & $\begin{array}{c}\text { No } \\
\mathrm{pH}-\mathrm{c}\end{array}$ & $\mathrm{pH}-\mathrm{c}$ & $\begin{array}{c}\text { No } \\
\text { aux }\end{array}$ & $\begin{array}{c}\text { No } \\
\mathrm{pH}-\mathrm{c}\end{array}$ & $\mathrm{pH}-\mathrm{c}$ & $\begin{array}{c}\text { No } \\
\text { aux }\end{array}$ & $\begin{array}{c}\text { No } \\
\mathrm{pH}-\mathrm{c}\end{array}$ & $\mathrm{pH}-\mathrm{c}$ \\
\hline 0.5 & 47 & 25 & - & 47 & 7 & - & 47 & - & - \\
\hline 3.0 & 53 & 36 & - & 53 & 13 & 26 & 53 & - & - \\
\hline 4.0 & 51 & 33 & - & 51 & 11 & - & 51 & - & - \\
\hline 5.0 & 37 & 35 & - & 37 & 5 & - & 37 & - & - \\
\hline 24.0 & 57 & 31 & - & 57 & - & - & 57 & - & - \\
\hline
\end{tabular}

The best removal efficiency was reached in the greywater when using an iron- $\mathrm{NH}_{4}+$ acid, as presented in Table 6 in $2.38 \mathrm{mg} / \mathrm{L}$ of the acid after $4-5 \mathrm{~h}$ decanting. Therefore, turbidity could be better removed when the small concentration of ascorbic acid was employed and using 24 $\mathrm{h}$ decanting is not worthy.

Table 6 - Turbidity removing for $\mathrm{Fe}\left(\mathrm{SO}_{4}\right) \mathrm{NH}_{4}$ and associated with ascorbic acid at three different concentrations. (No $\mathrm{pH}-\mathrm{c}: 2.3<\mathrm{pH}<4.0$ )

\begin{tabular}{|c|c|c|c|c|c|c|c|c|c|}
\hline \multicolumn{9}{|c|}{ Turbidity removing (\%) } \\
\hline \multirow{2}{*}{ Time/h } & \multicolumn{3}{|c|}{$2.38 \mathrm{mg} / \mathrm{L}$} & \multicolumn{3}{c|}{$7.14 \mathrm{mg} / \mathrm{L}$} & \multicolumn{3}{c|}{$11.9 \mathrm{mg} / \mathrm{L}$} \\
\cline { 2 - 11 } & $\begin{array}{c}\text { No } \\
\text { aux }\end{array}$ & $\begin{array}{c}\text { No } \\
\mathrm{pH}-\mathrm{c}\end{array}$ & $\mathrm{pH}-\mathrm{c}$ & $\begin{array}{c}\text { No } \\
\text { aux }\end{array}$ & $\begin{array}{c}\text { No } \\
\mathrm{pH}-\mathrm{c}\end{array}$ & $\mathrm{pH}-\mathrm{c}$ & $\begin{array}{c}\text { No } \\
\text { aux }\end{array}$ & $\begin{array}{c}\text { No } \\
\mathrm{pH}-\mathrm{c}\end{array}$ & $\mathrm{pH}-\mathrm{c}$ \\
\hline 0.5 & 85 & 65 & 2 & 85 & 9 & - & 85 & - & - \\
\hline 3.0 & - & 87 & 4 & - & 64 & - & - & 39 & - \\
\hline 4.0 & 2 & 88 & 5 & 2 & 70 & - & 2 & 35 & - \\
\hline 5.0 & - & 91 & 4 & - & 74 & - & - & 62 & - \\
\hline 24.0 & 38 & 95 & - & 38 & 59 & - & 38 & 46 & - \\
\hline
\end{tabular}

In general, the study showed that the enhanced coagulation process alone is not able to reduce the contaminants substances to the required reuse standard, thus it needs the application of additional processes or different kind of auxiliary chemical. 


\section{CONCLUSIONS}

The synthetic wastewater similarly produced in Brazilian residences was treated using traditional coagulants associated with ascorbic acid. All experiments with controlled $\mathrm{pH}$ resulted in treated greywater with increasing in conductivity and it was found significantly high when controlled $\mathrm{pH}$ was used in the coagulation process.

Coagulation experiments showed that $\mathrm{Al}_{2}\left(\mathrm{SO}_{4}\right)_{3}$ resulted to higher TS and turbidity removal comparing to $\mathrm{FeCl}_{3}$. The auxiliary coagulant dosage affected process efficiency.

The best removal efficiency was reached in the greywater when using an iron- $\mathrm{NH}_{4}+$ acid in all concentrations of the acid after 4-5 h decanting. Turbidity was better removed when the small concentrations of ascorbic acid was employed. Generally, enhanced coagulation process using ascorbic acid was not sufficient to meet turbidity $(<20 \mathrm{mg} / \mathrm{L})$ and TS $(100 \mathrm{mg} / \mathrm{L})$ limits. The highest turbidity removal (95\%) was obtained at the range of $2.0-4.3 \mathrm{pH}$ values.

\section{ACKNOWLEDGEMENTS}

The authors would like to thank CAPES and FAPEMIG ((Project PCE-00089-14) for the financial support.

\section{REFERENCES}

MERIÇ, S.; GUIDA, M.; MATTEI, M.; ANSELMO, A.; MELlUSO, G. Evaluation of coagulation flocculation process for S. Giovanni a Teduccio municipal wastewater treatment plant. Fresenius Envir. Bull., v.11, p. 906-909, 2002a.

MERIÇ, S.; GUIDA, M.; MATTEI, M.; ANSELMO, A.; MELLUSO, G.; PAGANO, G. Microbial and COD removal in a municipal wastewater treatment plant using coagulation flocculation process. J. Environ. Sci. Health, v. A37(8), p. 1483-1494, 2002 b.

DELGADO, S.; DIAZ, F.; GARCIA, D.; OTERO, N. Behavior of inorganic coagulants in secondary effluents from a conventional wastewater treatment plant. Filtr. Separ., v. 40(7), p. 42-46, 2003.

ROSSINI, M.; GARRIDO, J. G.; GALLUZZO, M. Optimization of the coagulationflocculation treatment: Influence of rapid mix parameters. Wat. Res., v. 33(8), p. 1817-1826, 1999.

SELÇUK, H.; KAPTAN, D.; MERIÇ, S. Coagulation of textile wastewater using alum and Fe(III) salts. Fresenius Environ. Bull., v. 13(10), p. 1045-1048, 2004.

VOLK, C.; BELL, K.; IBRAHIM, E.; VERGES, D.; AMY, G.; LECHEVALLIER, M. Impact of enhanced and optimized coagulation on removal of organic matter and its biodegradable fraction in drinking water. Wat. Res., v. 34(12), p. 3247-3257, 2000. 
RIZZO, L.; BELGIORNO, V.; GALLO, M.; MERIÇ, S. Removal of THMs precursors from a high-alkaline surface water by enhanced coagulation and behavior of THMFP toxicity on D. magna. Desalination, v. 176, p. 177-188, 2005.

GAO, B.Y.; H.H. HAHN; H. H., HOFFMANN, E. Evaluation of aluminium-silicate polymer composite as a coagulant for water treatment. Wat. Res., v. 36, p. 3573-3581, 2002a.

GAO, B.Y.; YUE, Q. Y.; WANG, B. J.; CHUA, Y. B. Polyaluminium-silicate-chloride (PASiC) - a new type of composite inorganic polymer coagulant. Colloids and Surfaces, v. 229(1-3), p. 121-127, 2003.

GAO, B. Y.; YUE, Q. Y.; MIAO, J. Evaluation of polyaluminium ferric chloride (PAFC) as a composite coagulant for water and wastewater treatment. Wat. Sci. Tech., v. 47(1), p.127$132,2002 b$.

Standard Methods for the Examination of Water and Wastewater. $20^{\text {th }}$ ed., American Public Health Association/American water Works Association/Water Environment Federation, Washington, DC, USA, 1998.

BONEBERG, D. G.; REVOLTA; B. S.; PIMENTA, P. S.; FRANCO JR, M. R. Removing general organic compounds from small quantities of river water. American Journal of Environmental Engineering. v.3(5), 2013.

ALMEIDA, J. S. M.; FRANCO JR, M. R. Dissolved oxygen measurements on Uberabinha River for determining the oxygenation constant. Anais do III CIMAS - São Paulo. Outubro de 2013.

ALMEIDA, J. S. M.; ROCHA, N. R. A. F.; FRANCO JR, M. R. Treating domestic greywater and expectations to be reused. American Journal of Environmental Engineering. v. 3(5), 2013. 